\title{
Pasture development during brush clearing with sheep and goats
}

\author{
M. ESSAM DABAAN, ANDREW M. MAGADLELA, WILLIAM B. BRYAN, BARBARA L. ARBOGAST, EDWARD \\ C. PRIGGE, GONZALO FLORES, AND JEFFREY G. SKOUSEN
}

Authors 1, 2 are graduate students, 3 is professor and 7 is associate professor, Division of Plant and Soil Sciences, West Virginia University, P.O. Box 6108, Morgantown, W. Va. 26506-6108. Author 4 is graduate student and 5 is professor, Division of Animal and Veterinary Sciences, West Virginia University, P.O. Box 6108, Morgantown, W. Va. 26506-6108. Author 6 is research scientist at the Investigaciones Agrarias, Xunta de Gulicia, Apartado 10, La Coruña, Spain.

\begin{abstract}
Knowing that sheep or goats can be used to control brush we quantified pasture changes during and after brush control. Over an 8-year period we measured the effects of control (no soil amendment), medium soil amendment $(4,500 \mathrm{~kg}$ lime and $40 \mathrm{~kg} P$ $\left.\mathrm{ha}^{-1}\right)$, and high soil amendment $\left(9,000 \mathrm{~kg}\right.$ lime and $\left.117 \mathrm{~kg} \mathrm{P} \mathrm{ha}^{-1}\right)$ on soil fertility, pasture botanical composition and production of brushy pasture grazed by sheep or goats. Botanical composition was estimated from clipped samples. Soil pH was 4.8 in the control, 6.5 in the medium and 7.0 in the high amendment plots. Medium and high amendment increased legume dry matter in the pasture from 2 in the check to $8 \%$. More animal grazing days were obtained on paddocks treated with lime and P. Grazing with sheep or goats and lime and application of $P$ resulted, after 4 years, in pastures with a grass, legume, and other broadleaf plant composition similar to that of brush-free, natural pasture.
\end{abstract}

Key Words: grazing, pasture fertilization, lime, phosphorus, natural pasture, stocking density

Productive grassland is the mainstay of the beef and sheep industries in the northeastern United States. More than $50 \%$ of farm income in West Virginia comes from selling livestock products. West Virginia pasture production is often low, mainly due to low soil fertility and brush invasion. In West Virginia, about 43,000 ha of farmland are seriously infested with weeds or brush and some type of control is needed. Pasture in this region can be reclaimed by using grazing animals for brush clearing (Magadlela et al. 1995, Mills 1984) and by adding lime and P to the soil (Bryan et al. 1987).

Several investigators have demonstrated that grazing animals such as sheep (Ovis aries L.), goats (Capra hircus L.), and cattle (Bos taurus L.) can change the nature of existing vegetation and increase pasture utilization for animal production. Crouchley (1983) reported that blackberry bushes (Rubus sp.) more than $3 \mathrm{~m}$ high were killed or damaged by goats, which allowed white

This research was partially funded by Tennessee Valley Authority under contract TV-19017 and with funds appropriated under the Hatch Act. This information is published with the approval of the Director of West Virginia Agriculture and Forestry Experiment Station as Scientific Article \# 2470.

The authors gratefully acknowledge the help and enthusiasm of Kenneth and Karen St. Louis on whose land this experiment was conducted.

Manuscript accepted 9 Jun. 1996. clover (Trifolium repens L.) and perennial ryegrass (Lolium perenne L.) establisliment. Clark et al. (1982) suggested that sheep and goats grazed together could control gorse (Ulex sp.), increase total animal product per unit area, and increase the amount of white clover available to sheep. A comparison of diets of goats and sheep on brush-infested pasture showed that goats preferred brush (Prigge et al. 1985). On brush-free pasture both goats and sheep preferred grass over legumes.

Another important factor which affects pasture productivity is suil $\mathrm{pH}$. Optimum yield of white clover was obtained at $\mathrm{pH} 6.0$ or above (Pearson and Hoveland 1984). Koch and Estes (1986) found that forage legume establishment was improved when applied lime raised soil $\mathrm{pH}$ from 5.6 to 6.1. McLachlan (1980) found that liming increased clover nodulation. Mills (1984) demonstrated that after overseeding pasture with red clover ( $T$. pratense L.), the amount of red clover in lime- and P-amended plots was $7 \%$ compared to only $2 \%$ for unamended plots.

An experiment was carried out using a combination of sheep, goats, and soil amendment to improve brush-infested pastures in West Virginia. The effects of the treatments on brush control were published by Magadlela et al. (1995). A second objective was to compare the effects of sheep and goats and of 2 levels of lime and $\mathrm{P}$ application on botanical composition and production of brush-infested hill land pasture.

\section{Methods and Materials}

The experiment was conducted on a $500,000 \mathrm{kV}$ power line right-of-way on a private farm near Morgantown, W. Va. Soils were classified as Westmoreland (fine-loamy, mixed, mesic Typic Fragiudalfs) and Clarksburg series (fine-loamy, mixed, mesic Ultic Hapludalfs). The experimental area was selected in 1985 as a typical West Virginia hill land, brush-infested pasture. The site was last treated with chemicals before 1978 by the power company. Cattle grazing an adjoining pasture had access to the area before initiation of the study. No lime or fertilizer had been applied for at least 10 years previously according to land owners. The vegetation on the site was described in detail by Magadlela et al. (1995) in which the principal grasses were: Kentucky bluegrass (Poa pratensis L.), Velvet grass (Holcus lanatus L.), broomsedge (Andropogon virginicus L.), and poverty grass [Danthonia spicata (L.) Beauv.]. Brush covered almost $50 \%$ of 
the area, was about $1.25 \mathrm{~m}$ tall and consisted primarily of Rubus spp. and Smilax rotundifolia L.

An area of $1.8 \mathrm{ha}$, on northeast facing slopes ranging from 0 to $65 \%$ (14\% average), was divided into 12 paddocks, each 1,500 $\mathrm{m}^{2}$ in size. Two animal species and 3 soil treatments were applied in a $2 \times 3$ factorial arrangement. A randomized complete block design with 2 replications was used. The 3 soil treatments were: 1) no lime or $P$; 2) medium lime and $P$, in which lime was added with the goal of raising the $\mathrm{pH}$ above 5.4 and triple superphosphate (0-44-0) was applied to maintain available $P$ at or above 45 $\mathrm{kg} \mathrm{ha}^{-1}$; 3) high lime and $\mathrm{P}$, where lime and $\mathrm{P}$ were applied to raise the $\mathrm{pH}$ above 5.8 and provide available $\mathrm{P}$ above $67 \mathrm{~kg} \mathrm{ha}^{-1}$.

Soil samples ( 0 to $2.5 \mathrm{~cm}$ ) were taken from each paddock (minimum of 30 cores per paddock) in October 1985. Starting in 1987, sampling was repeated annually in October. Soil samples were air dried and analyzed by procedures of Ghazi et al. (1978). Soil test results were used to determine lime and $\mathrm{P}$ applications. When soil $\mathrm{pH}$ dropped below the assigned treatment level, 4,500 $\mathrm{kg} \mathrm{ha}^{-1}$ of lime were applied, which is the standard West Virginia soil test laboratory recommendation for pasture. Phosphorus was applied at $20 \mathrm{~kg} \mathrm{ha}^{-1}$ for every $10 \mathrm{~kg} \mathrm{ha}^{-1}$ that soil available $P$ was below the target level. Soil available $\mathrm{K}$ levels were very high (above $270 \mathrm{~kg} \mathrm{ha}^{-1}$ ) on all treatments, therefore, no $\mathrm{K}$ was added.

Dolomitic limestone was applied to medium and high lime treated paddocks in October 1986. Triple superphosphate was applied to the same paddocks in April 1987. The average rate of $\mathrm{P}$ application was $28 \mathrm{~kg} \mathrm{ha}^{-1}$ for medium and $67 \mathrm{~kg} \mathrm{ha}^{-1}$ for high applications. Ground limestone was applied again in April 1989 to high lime treated paddocks. This second application of lime was made to separate high and medium treatments. In June 1990 , $P$ was applied at $50 \mathrm{~kg} \mathrm{ha}^{-1}$ to high treatment paddocks and $6 \mathrm{~kg}$ $\mathrm{ha}^{-1} \mathrm{P}$ to medium treatment paddocks. The $\mathrm{P}$ application to medium paddocks was repeated in April 1991. Limestone was broadcast by hand and triple-superphosphate with a hand-operated fertilizer spinner.

Animal treatments were applied in 3 phases (Fig. 1). Each paddock was grazed rotationally at a fixed stocking rate of either 3 sheep or 3 goats in the first phase (1986-1988). Polywire electric fence was used to divide each paddock into 4 equal sections, and animals were allowed on each section for 3 to 10 days depending on available forage. A total of 18 Suffolk cross sheep (dry ewes) and 18 Toggenburg or Saanen goats were used. In 1986, grazing could not begin until early August because fences and water were not in place. Internal polywire fences were not put up until 1987. In 1987 and 1988, all animals were removed in July and August because of dry weather.

In the second phase (1989-1990), each paddock was divided in half (Fig. 1). Sheep alone grazed one half and sheep followed by or combined with goats grazed the other. Half plots were rotationaly grazed for 1 to 4 days by 27 sheep and 12 goats in 1989 , and 24 sheep and 15 goats in 1990. Rest periods depended on plant growth rate. Sheep were turned onto the pasture when herbage mass was 1,000 to $1,500 \mathrm{~kg} \mathrm{ha}^{-1}$, and were removed when herbage mass decreased to 500 to $750 \mathrm{~kg} \mathrm{ha}^{-1}$. Goats were removed when brush had been 90-100\% defoliated (determined visually). Animals grazed other areas when not on experimental paddocks. In phase I, animals grazed rotationally within each paddock. In phases II and III, animals grazed rotationally between paddocks.

In the third phase of the experiment (1991-1993), fences dividing the paddocks in half were removed and entire paddocks were
PHASE I (1986-88): Paddocks divided in four, grazed rotationally with 3 animals
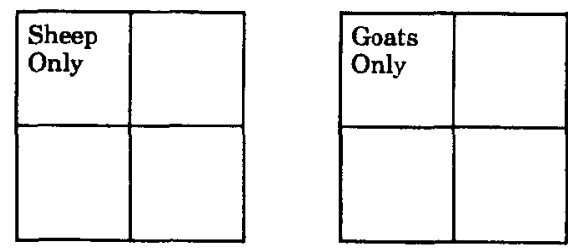

PHASE II (1989-90): Paddocks divided in two, grazed by sheep, or by sheep and goats together
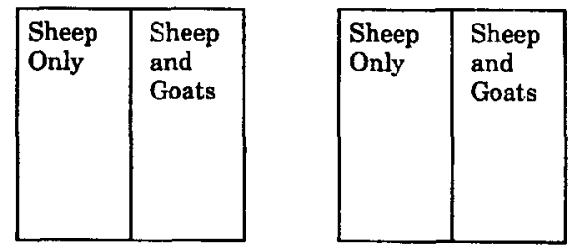

PHASE III (1991.93): Entire paddock grazed by sheep and goats together
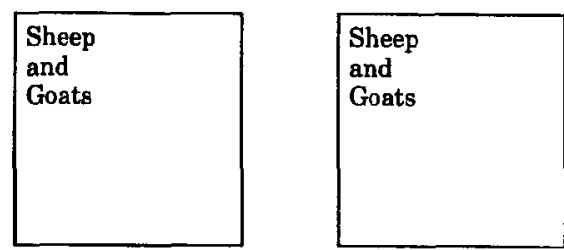

Fig. 1. Diagramatic representation of 2 experimental paddocks showing differences in animal treatments in the 3 phases of the experiment.

grazed with sheep and goats using the same management as used in the second phase (Fig. 1). However, sheep numbers were increased to 50 and goat numbers were reduced to 6 , since brush had been reduced to low growing plants by the end of phase II.

The effects of animal species were compared only in phases I and II. Only data from one half of each paddock were used from phase II for this purpose. In phase II, data from the sheep only half-paddock were used for the sheep treatment, and data from the sheep and goat half-paddock were used for the goat treatment.

In March 1987 and 1988, the entire area was overseeded with red clover and Kentucky bluegrass using a hand-operating spinner. Red clover was inoculated with the appropriate Rhizobium. Data were classitied into grazing cycles. For phase I, each cycle consisted of the time from initiating grazing of the first subdivision of the paddock until animals were removed from the last (fourth) subdivision. For phases II and III, each grazing was a cycle.

In phase I, herbage mass in each subdivision was measured by clipping five $0.2 \mathrm{~m}^{2}$ areas selected at random. Herbage removed was calculated as the difference between herbage mass before and after grazing plus growth rate multiplied by number of grazing days. Growth rates were estimated from concurrent experiments (Bryan and Mills 1988). Herbage mass and herbage removed were averaged for the 4 subdivisions to provide values for each cycle. In phase II (1989-1990), herbage mass was estimated from the average of 20 sward height measurements (Bircham 1981) used in prediction equations. These equations, 
which may be obtained from the authors, were calculated from regression analyses of paired data, sward height and dry matter. These data were taken by measuring sward height in four $0.2 \mathrm{~m}^{2}$ areas per half paddock. The $0.2 \mathrm{~m}^{2}$ areas as were then clipped by hand at $1-2 \mathrm{~cm}$ and the vegetation dried. The same procedure was used in the first year of phase II (1991). In 1992 and 1993, no clipped samples were taken, and prediction equations were used that had been developed from combined data for 1989-1991 for each cycle. Herbage removed was calculated as the difference between herbage mass before and after grazing.

Clipped samples were hand-separated into grass, legume, other broad-leaved plants, and dead material, and then dried and weighed. These data were used to calculate percent botanical composition. The number of animal grazing days was calculated by multiplying the number of grazing animals by the number of days grazing. Herbage mass before and after grazing and days of grazing are presented as the mean per grazing cycle. Herbage removed and animal grazing days are totals per year.

Statistical analyses were performed using the General Linear Model procedure (SAS Institute 1985). The experimental design was a split plot over time (years) with a completely randomized block design on the whole plot (paddock). A factorial arrangement of animal species (sheep and goats) and soil amendment (control, medium, and high) was applied to each block (6 paddocks). Animal species, soil amendment and years were fixed effects. Animal species, soil amendment effects, and their interaction were tested using the block $X$ animal species $X$ soil amendment interaction. Soil amendment treatments were compared with 2 orthogonal comparisons: 1) no amendment vs. the medium and high amendments, and 2) medium vs. high amendment. Year was treated as a split plot in time. Differences were deemed significant at $\mathbf{P}<0.10$. Data from this experiment on brush control have already been published (Magadlela et al. 1995).

\section{Results and Discussion}

Dolomite application in 1986 increased soil $\mathrm{pH}$ on medium and high lime and $\mathrm{P}$ treated paddocks (Fig. 2). The second application of lime increased $\mathrm{pH}$ in the $02.5-\mathrm{cm}$ depth to about 7. Soil $\mathrm{pH}$ of paddocks with no amendment fluctuated near 5.0. Application of $P$ increased soil available $P$, and the higher rate produced the desired effect of a soil test well above $67 \mathrm{~kg} \mathrm{ha}^{-1}$ except in 1989 (Fig. 3). The low P test in 1989 for these paddocks seems to be an anomaly and resulted in a decision to apply $50 \mathrm{~kg} \mathrm{Pha}^{-1}$ in 1990. This application, in turn, resulted in a large increase in available soil $P$. There was no effect of soil amendment or year on available $\mathrm{K}$ (data not shown). Animal species had no effect on soil $\mathrm{pH}$, available $\mathrm{P}$ or $\mathrm{K}$ (data not shown).

Before the experiment began, $45 \%$ of the area was covered with brush (Table 1) (canopy cover, estimated visually each year before grazing started). There was no effect on brush in 1986 because grazing did not start until August. Goats reduced brush cover to about $15 \%$ in 1987 . Sheep took 2 more years to bring about the same result. At the end of phase II (1990), brush on all paddocks was 0 to $5 \%$ of plant cover (Magadlela et al. 1995).

Applying lime and $\mathrm{P}$ increased percentage legume from $2 \%$ in the control to an average of $8 \%$ in the amended treatments $(\mathrm{P}<0.05)$ (Fig. 4). Level of lime and $\mathrm{P}$ amendment did not affect legume content of the pasture until 1991. In 1991, percent legume

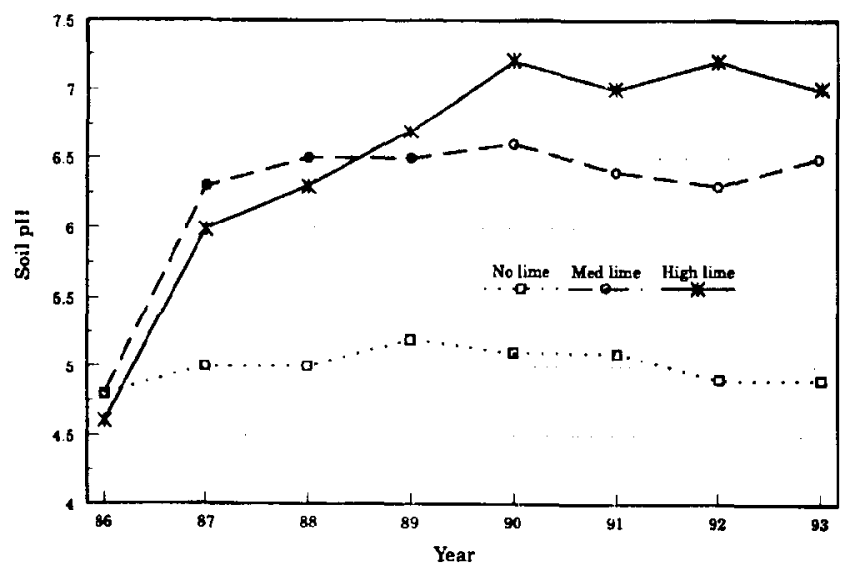

Fig. 2. Soil $\mathrm{pH}(0-2.5 \mathrm{~cm})$ as affected by lime application and time. Dolomite $\left(4,500 \mathrm{~kg} \mathrm{~h}^{-1}\right)$ was applied in October 1986 (to medium and high paddocks) and lime $\left(4,500 \mathrm{~kg} \mathrm{ha}^{-1}\right.$, to high paddocks) in April 1989. Soil was sampled in October of each year. Effects of lime and $P$ application, year, and their interaction were highly significant. Contrast between no application and application was highly significant. Cuntrast between medium and high applications was not significant.

increased dramatically in paddocks to which high levels of lime and $P$ were applied. This may have been a result of increased available $P$ in 1990 anıl 1991 (Fig. 3). More available P may also have favored more palitable grasses, which resulted in closer grazing and less competition from the grass component.

As the experiment progressed, the contribution of grass to the herbaceous vegetation increased, and that of other broadleaf plants and dead material decreased (Table 1). Precent legume was highest in 1991 and lowest in 1987. By 1991, the pasture had hecome grass dominant and had a botanical composition approaching that of brush-free pastures in the area (Bryan et al. 1987).

The first overseeding of red clover in March 1987 was followed by an increase in legume content of herbage from $2 \%$ in 1987 to $10 \%$ in 1988 . Most of this increase in legume content was red clover. Legume content in the pasture was low again in 1989, despite the second overseeding in March 1988. This was probably due to the dry June of 1988, and resultant heavy grazing due to set stocking. However, legume content again increased in the pastures in 1990 and 1991 and was mostly white clover (Fig. 4).

Animal species had no effect on percentages of grass, legume, other broadleaf plants, or dead material in the pasture. Sheep grazed more closely than goats, and herbage mass after grazing

Table 1. Effect of year on pasture composition before grazing each year.

\begin{tabular}{|c|c|c|c|c|c|}
\hline Year & Brush & Grass & Legume & \multicolumn{2}{|c|}{ Other broadleaf plants Dead } \\
\hline & - - (\% cover $)$ - - & \multicolumn{4}{|c|}{$\ldots \ldots$ (\% of herbage dry mattcr) $\ldots \ldots \ldots$} \\
\hline 1986 & 45 & 21 & 4 & 42 & 33 \\
\hline 1987 & 45 & 23 & 2 & 52 & 22 \\
\hline 1988 & 28 & 28 & 10 & 51 & 11 \\
\hline 1989 & 28 & 46 & 3 & 35 & 16 \\
\hline 1990 & 9 & $6+1$ & 6 & 20 & 9 \\
\hline 1991 & 3 & 68 & 13 & 11 & 9 \\
\hline
\end{tabular}

Highly significant effects of year for all columns.

No significant interactions, except highly significant interaction between animal species and years for brush (see Magadlela et al. 1995). 
Table 2. Herbage mass after grazing, pasture removed, days of grazing, and animal grazing days as affected by animal species and soil amendment.

\begin{tabular}{|c|c|c|c|c|}
\hline & $\begin{array}{c}\text { Herbage mass } \\
\text { after } \\
\text { grazing }\end{array}$ & $\begin{array}{l}\text { Herbage } \\
\text { removed }\end{array}$ & $\begin{array}{l}\text { Days of } \\
\text { grazing }\end{array}$ & $\begin{array}{l}\text { Animal } \\
\text { grazing } \\
\text { days }^{2}\end{array}$ \\
\hline Animal species ${ }^{3}$ & \multicolumn{2}{|c|}{$\ldots\left(\mathrm{kg} \mathrm{ha}^{-1}\right) \ldots$} & (\#) & $\left(\#\right.$ plot $\left.^{-1}\right)$ \\
\hline Goats & 797 & 2281 & 4.9 & 335 \\
\hline Sheep & 631 & 2311 & 4.6 & 287 \\
\hline \multicolumn{5}{|l|}{ Soil amendment ${ }^{4}$} \\
\hline No lime and $P$ & 669 & 2301 & 3.0 & 257 \\
\hline Medium lime and $P$ & 654 & 3025 & 3.7 & 330 \\
\hline High lime and $P$ & 691 & 2785 & 3.6 & 332 \\
\hline Contrast $1^{5}$ & ns & ns & + & + \\
\hline Contrast $2^{6}$ & ns & ns & ns & ns \\
\hline
\end{tabular}

$+\mathrm{P}<0.10, * \mathrm{P}<0.05$. No significant interactions.

Average number of days each paddock was grazed each cycle.

${ }^{2}$ Number of animals by number of days of grazing, total for the year.

${ }^{3}$ Excludes 1986, 1991, 1992, and 1993.

${ }^{4}$ Excludes 1986 and 1987.

${ }^{5}$ Contrast $1=$ No lime or $P$ compared to lime and $P$.

${ }^{6}$ Contrast $2=$ Medium lime and $\mathrm{P}$ compared to high lime and $\mathrm{P}$.

was lower on paddocks grazed by sheep than on those grazed by goats (Table 2). However, there was no significant difference between animal species in amount of herbage removed. There were no differences between animal species in number of days paddocks were grazed each cycle, or in number of animal grazing days per year. This is not unexpected because the same numbers of animals were used in the first 3 years (phase I), and all plots were grazed by sheep in phase II.

Soil treatment did not affect herbage mass after grazing or herbage removal. However, amended paddocks were grazed longer (days of grazing) and accomodated more animals (animal grazing days) than the control. These differences were not significant in 1986 and 1987. We interpret these differences, along with observations on changes in species composition of grasses, as follows. Initially, predominant grasses were poverty grass and

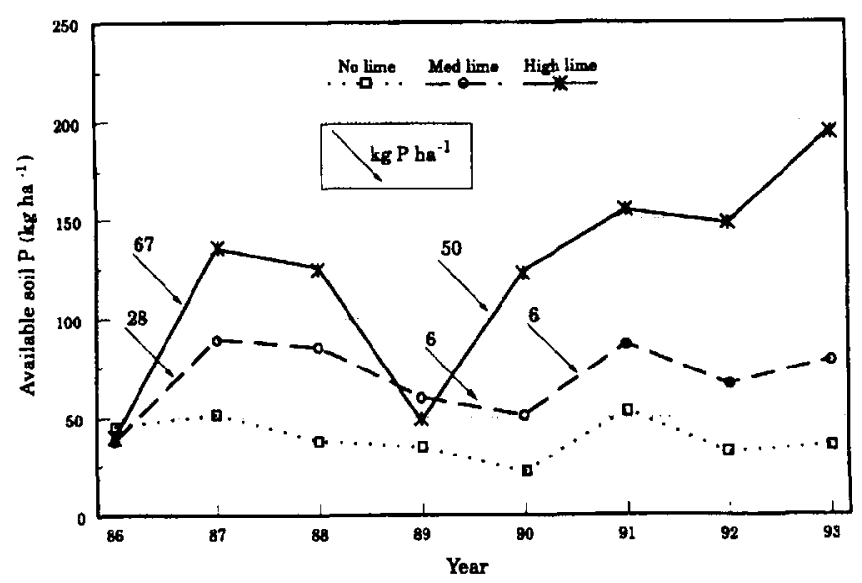

Fig. 3. Available soil $P(0-2.5 \mathrm{~cm})$ as affected by lime and $P$ application and time. Triple superphosphate was the source of $P$, and was applied in April 1987, June 1990, and April 1991 in amounts indicated at arrows. Soil was sampled in October of each year. Effects of lime and $P$ application, year, and their interaction were highly significant. Contrasts between no application and application and between the medium and high applications were highly significant.

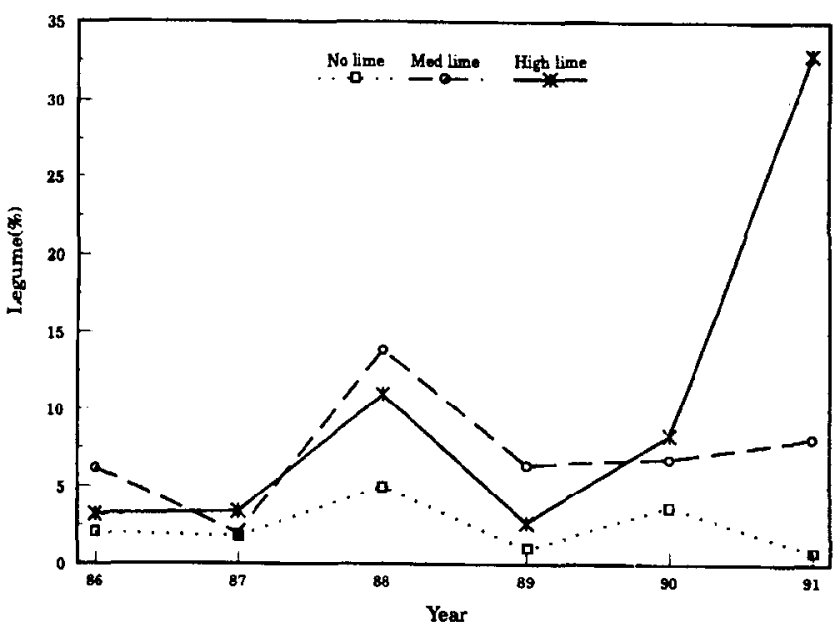

Fig. 4. Percentage legume in the pasture dry matter as affected by lime and $P$ application and time. Medium lime was $4,500 \mathrm{~kg} \mathrm{ha}^{-1}$. Medium $P$ was $40 \mathrm{~kg} \mathrm{ha}^{-1}$ and high $P 117 \mathrm{~kg} \mathrm{ha}^{-1}$. No lime or $P$ was significantly lower than lime and $P$. There was no difference between medium and high lime and $P$. Effect of year was highly significant.

broomsedge. Brush cover was reduced starting in 1987, and grass and legumes increased in 1988 (Table 1). Soil amendment with lime and $\mathrm{P}$ had no effect until 1988 because, first, they act slowly in the soil and, second the herbaceous component of the pasture was developing. From 1988, Kentucky bluegrass and velvet grass increased on amended paddocks and by 1991 had largely replaced broomsedge and poverty grass. Animals preferred Kentucky bluegrass and velvet grass and carrying capacity increased compared to control paddocks. Vegetative cover on control paddocks was adequate, but animals did not utilize it as well because it consisted mainly of broomsedge and poverty grass.

\section{Conclusions}

Initially, limiting factors to pasture change were brush cover and low soil $\mathrm{pH}$. As brush was cleared by the animals and $\mathrm{pH}$ was increased by dolomitic limestone, the limiting factor on amended paddocks became N. Red clover supplied some N. It took 2 years (excluding 1986, since grazing started too late to have a permanent effect on brush) to increase grass appreciably and reduce broadleaf plants. In 4 years, the pastures reached a botanical composition typical of brush-free pasture. The key issues were application of lime and $P$ in combination with grazing management that utilized vegetation well. Application of lime and $P$ increased legume contribution in the pasture (Fig. 4). Available $P$ levels over $150 \mathrm{~kg} \mathrm{ha}^{-1}$ may have promoted higher legume content. The relationship between soil available $P$ and legume contribution should be examined more precisely. Species of grazing animal, very significant for brush clearing (Magadlela et al. 1995), was less important in promoting botanical composition changes in pasture being cleared of brush.

Grazing management was very important in brush control (Magadlela et al. 1995) and pasture renovation. Although grazing management methods were not treatments in our experiment, 
grazing was changed from rotational with fixed stocking in phase I to rotational with variable stocking in phases II and III. Our observations suggest that the grazing management that provided the best opportunity to manipulate pasture botanical composition was rotational with variable stocking. This means that time and intensity of grazing can be changed to favor some plant species and to control others. We believe it is critical to graze early and force animals to remove the majority of the vegetation. This promotes grass growth and controls broadleaf plants. Heavy grazing of poverty grass and broomsedge in early growth stages, concurrent with lime and $P$ application, results in reduction in these species. On non-amended paddocks, the same grazing management led to better utilization of these lower quality grasses but did not result in an increase in more desireable grass species presumably because the limiting factor was soil fertility.

\section{Literature Cited}

Bircham, J.S. 1981. Herbage growth and utilization under continuous stocking management. PhD. Thesis. University of Edinburgh, U.K.

Bryan, W.B. and T.A. Mills. 1988. Seasonality of pasture growth in West Virginia, pp. 382-386. In: Proc. 12th Meeting of the European Grassl. Federation. Dublin, Ireland.

Bryan, W.B., T.A. Mills, and F.X. Rosica. 1987. Effects of grazing management and soil amendment on hill land pasture botanical composition. Appl. Agric. Res. 1:297-302.
Clark, D.A., M.G. Lambert, M.P. Rolston, and N. Dymock. 1982. Diet selection by goats and sheep on hill country. Proc. N.Z. Soc. Anim. Prod. 42:155-157.

Crouchley, G. 1983. Blackberry control in Hawkes Bay. pp. 63-64. In: Proc. Ruakura Farmer's Conf. Hamilton, N.Z.

Ghazi, H., W.A. Van Fck, and L. Bennett. 1978. Soil testing methods. Soil Fertility Information Series No. 3. West Virginia Univ. Morgantown, W. Va.

Koch, D.W. and G.O. Estes. 1986. Liming rate and method in relation to forage cstablishment-crop and soil chemical responses. Agron. J. 78:567-571.

Magadlela, A.M., M.E. Dabaan, W.B. Bryan, E.C. Prigge, J.G. Skousen, G.E. D'Souza, B.L. Arbogast, and G. Flores. 1995. Brush clearing on hill land pasture with sheep and goats. J. Agron. Crop Sci. 174:1-8.

McLachlan, K.D. 1980. Nutrient problems in sown pasture on an acid soil. 2 Role of lime and superphosphate. Austr. J. Expl. Agr. Anim. Husb. 20:568-575.

Mills, T.A. 1984. Improving hill land pasture with grazing animals. M.S. Thesis. West Virginia Univ. Morgantown, W. Va.

Pearson, R.W. and C.S. Hoveland. 1984. Lime needs of forage crops. pp. 301-322. In: D.A. Mays (ed.). Forage fertilization. Amer. Soc. Agron. Madison, Wis.

Prigge, E.C., D.B. Mpiri, and W.B. Bryan. 1985. Composition and nutritive value of diets selected by sheep and goats on four pasture types. pp. 998-999. In: Proc. XV Int. Grassl. Congr. Kyotn, Japan.

SAS Institute, Inc. 1985. SAS User's Guide: Statistic Version 5th Edition. Cary, N.C. 